\title{
21. PLANKTONIC CRINOIDS OF LATE JURASSIC AGE FROM LEG 11, DEEP SEA DRILLING PROJECT
}

\author{
Hans Hess, Museum of Natural History, Basel, Switzerland
}

\begin{abstract}
Remains of saccocomids are described from ten samples of Sites 99, 100, and 105. They embrace a few isolated radials but mainly brachials. The radials and some of the brachials can be assigned to Saccocoma cf. schattenbergi Sieverts-Doreck and $S$. cf. subornata Sieverts-Doreck (manuscript names). Broken-off bifurcated extensions of Saccocoma cf. quenstedti Sieverts-Doreck (manuscript name) are also quite common in some of the samples. Similar saccocomids have been reported from the Upper Jurassic (Middle to Upper Oxfordian and Lower Kimmeridgian) of Southern Germany and Southeastern France. Most of the remains belong to planktonic saccocomids (S. cf. quenstedti and $S$. cf. subornata), but $S$. cf. schattenbergi does not appear to have been purely planktonic. The material may contain some new species but is not rich enough to warrant establishment of new taxa.
\end{abstract}

Through Dr. H. P. Luterbacher I obtained a series of samples with isolated skeletal pieces of echinoderms for examination. With a few exceptions, the pieces belong to crinoids of the Order Roveacrinida. Since Jurassic roveacrinids ("Saccocoma") are very frequently encountered in thin sections of pelagic limestones (Brönnimann, 1955; Colom, 1955; Verniory, 1954, 1956; Farinacci and Sirna, 1959; and others), I have found it useful to include quite a number of better preserved specimens, in spite of the difficulties involved in the identification of many of the pieces.

For the careful drawings, rendered possible by a grant of the Swiss National Science Foundation, the author is indebted to Mr. O. Garraux-Schmid (Basel), and for the Stereoscan micrographs to Miss C. Brücher of Geigy Ltd. (Basel). Mrs. H. Doreck (Stuttgart), foremost authority on Jurassic saccocomids, has offered most valuable comments on the specimens which are illustrated in this paper.

Isolated skeletal pieces of Mesozoic planktonic crinoids similar to those described here have been assigned to the order Roveacrinida Sieverts-Doreck, with the families Saccocomidae d'Orbigny and Roveacrinidae Peck (Jaekel, 1892; Bather, 1924; Sieverts-Doreck, 1933, 1943, 1955; Peck, 1943, 1948, 1955; Verniory, 1960, 1961, 1962; Rasmussen, 1961). Species of Roveacrinidae have been recorded from the Triassic of Mexico (Peck, 1948), but also occur in great profusion in Cretaceous strata (see Rasmussen, 1961). The Saccocomidae reach their peak in the Jurassic. Extensive research on saccocomids (mainly from the Lower
Kimmeridgian) of Southern Germany is being conducted by $\mathrm{H}$. Sieverts-Doreck; the respective publications are, unfortunately, not yet available.

The crinoids examined here have a very small, stemless calyx (theca), which consists mainly of 5 radials, and mostly delicate brachials which often show processes to facilitate planktonic life. The skeleton is largely reticulate. On the calyx, two primibrachials ( $\mathrm{IBr}_{1}$ and $\left.\mathrm{IBr}_{2}\right)$ are articulated; the second primibrachial is axillary and bears two arms (secundibrachials) which may branch again in the subfamily Saccocominae (tertibrachials etc). The articulation between radials and first primibrachials is muscular (Figures 46 and $47 \mathrm{c})$ while the articular face of $\mathrm{IBR}_{1-2}$ is synarthrial, or rather, cryptosynarthrial, and in most cases strongly outward-sloping (Figures 11 and 48). Typical synarthrial articulations show a fulcral ridge separating two bundles of ligament fibers. In the present material, only ill-defined articulations of the synarthrial type have been observed. These are called cryptosynarthrial, and it is difficult to decide whether or not they belong to the synostosial type (ligamentary articulations without ridge). The distal articular face of the second primibrachial or first axillary (IAx) is again muscular (Figures $10 \mathrm{c}$ and $53 \mathrm{c}$ ). Some of the brachials have pinnule sockets (Figure 43).

Even though many of the pieces are hard to classify, it has nevertheless been possible to identify quite a number of them. The majority of the elements belong to species of Saccocoma, and three of them can be assigned provisionally to species being described by 
Sieverts-Doreck as from the Upper Jurassic of Germany. According to Mrs. Doreck the material might contain up to five new species (Figure 9, Figures 10, 11 and 13; Figure 22; Figure 25; Figure 45). It is, however, not abundant enough to justify the creation of any new species, especially because it does not contain any radials. With such fossils, it is obvious that taxonomy must take into consideration the individual variation, the ontogenetic level and of course the location of the pieces in the arms; and, for this the material must be rich.

All the drawings show the pieces enlarged 20 times, while the Stereoscan magnifications are enlarged about 70 times. Most of the brachials are figured with their ventral side upwards (as in real life); this is not the case with the side views (Figures 9c, 21c, 22a, 23a, and $27 \mathrm{c})$.

The bifurcated elements, most probably broken-off lateral extensions of saccocomid radials (cf. Verniory, 1961, Figure 1), are figured with their ends downwards.

Echinoderm remains are available from the following samples:

* 99A - 14, core catcher (Figures 54 and 55)

* 100-4-1, 12-14 cm (Figures 1-6, 56, 57)

* 100-4-1, 130-132 cm (Figures 7-9)

* 100-5-2, 18-20 cm (Figures 10-16, 64, 65)

* 100-5, core catcher (Figures 46-53, 60, 61, 63)

* 100-6-1, 19-21 cm (Figures 17-23, 58, 62) $100-8-2,130-132 \mathrm{~cm}$ $105-33-2,20-33 \mathrm{~cm}$

* 105-33-4, 10-30 cm (Figures 24-27) $105-34-2,18-25 \mathrm{~cm}$ $105-35-4,44-60 \mathrm{~cm}$

* 105-37-3, 22-40 cm (Figures 28-36, 61)

* 105-38-2, 64-80 cm (Figures 44 and 45)

* 105-38-5, 12-30 cm (Figures 37-43) $105-38$, core catcher

The samples marked with an asterisk have yielded material suitable for description.

\section{A - 14, Core Catcher (Figures 54 and 55)}

This sample contains two (distal ?) brachials and six more elements, two of them bifurcated (Figures 54 and 55). These appear to represent broken-off lateral extensions of saccocomid radials (see next sample).

100-4-1, 12-14 cm (Figures 1-6, 56, 57)

More than 50 bifurcated elements such as those shown in Figures 1 through 4 and 57 are available from this sample. They most probably represent brokenoff lateral extensions of radials of Saccocoma cf. quenstedti Sieverts-Doreck (manuscript name) (see Verniory, 1961, Figure 1). This species has been recorded from the Upper Oxfordian of Sisteron, Provence (Verniory, 1961) and from the Lower Kimmeridgian of Germany (Sieverts-Doreck). The face for the articulation of the first primibrachial is quite small on these pieces and usually only the nerve canal is clearly visible. (Figures 2a, 57, see also Figure 34b). The two ends of these pieces are typically branched. The somewhat different shape of the element of Figure 4 leaves some doubt as to its position; it might equally represent a brachial with ventral (upper) and smaller dorsal (lower) extensions.

Half a dozen pieces resemble the brachials of Figures 6 and 56, probably higher secundibrachials of a Saccocoma species. The element of Figure 5 cannot be definitely positioned but it may be a saccocomid primibrachial.

The lateral extensions on the radials of saccocoma $\mathrm{cf}$. quenstedti as well as the structure of the brachials with wing-like lateral extensions (Figures 6 and 56) suggest evidence of a purely planktonic life of these crinoids.

\section{0-4-1. 130-132 cm (Figures 7-9)}

The skeletal pieces from this sample are somewhat corroded. They are generally rather robust, but four bifurcated elements (Saccocoma cf. quenstedti) also occur. A lateral shield of an ophiuroid is also present.

The piece of Figure 7 is thought by Mrs. Doreck to be a juvenile radial from the group of Saccocoma cf. schattenbergi Sieverts-Doreck (manuscript name). If this is true, Figure $7 \mathrm{c}$ must be turned $180^{\circ}$.

Figure 8 shows an indeterminable saccocomid brachial, while Figure 9 seems to represent a first primibrachial of an unknown (new ?) Saccocoma species. If this were the case, the piece would be very long and slender.

100-5-2, 18-20 cm (Figures 10-16, 64, 65)

Only brachials have been found in this sample. Their dorsal surface is usually coarsely reticulate.

The elements of Figures 10, 11 and perhaps 13 seem to represent a new species of Saccocoma. Figure 11 is a first primibrachial with the proximal muscular face (c) and the outward-sloping distal cryptosynarthrial face (a). Figures 10, 64 and 65 show the axillary second primibrachial, the proximal face $(10 \mathrm{a}, 64)$ corresponding to the cryptosynarthrial distal face of the $\mathrm{IBr}_{1}$.

Figures 15 and 16 show indeterminable saccocomid brachials (first primibrachials ?). The small element of Figure 14, a brachial, is assigned by Mrs. Doreck to 
Saccocoma cf. subornata, Sieverts-Doreck (manuscript name). The piece of Figure 12 is difficult to assign to a particular position in the skeleton; it cannot represent a radial because of its contour (Figure 12b), and it does not seem to be an axillary because the muscular distal faces are lacking.

\section{0-5, Core Catcher (Figures 46-53, 59, 60, 63)}

This sample offers the best preserved and most numerous material. Most of the elements, more than 100 in total, can be assigned to a single species Saccocoma cf. schattenbergi Sieverts-Doreck (manuscript name), known from Middle to Upper Oxfordian of Germany and France (Verniory, 1962).

Figures 46 and 47 represent radials, the one of Figure 47 showing that these radials had interradial processes, which are completely broken off in the piece of Figure 46. The theca must have been quite robust, and the muscular face (Figures $46 \mathrm{c}$ and $47 \mathrm{c}$ ) is relatively broad but not outward-sloping. The radials were connected by close synostosis, the nerve canals on the faces being clearly visible. On these radials, first primibrachials (as the one shown in Figure 48) were inserted. Here again the cryptosynarthrial distal-articular face is strongly outward-sloping. A second primibrachial $\left(\mathrm{IBr}_{2}=\mathrm{IAx}\right)$ is shown in Figure 53.

Proximal brachials, presumably also belonging to $S$. cf. schattenbergi are represented in Figures 49, 50, 59, 60, and 63. Muscular faces $(49 a, 50 a, 59)$ are alternating with cryptosynarthrial or synostosial faces (49 and $50 \mathrm{~b}, 60)$. Some of the more slender secundi- or even tertibrachials have pinnule sockets. (Figure 63), while other brachials have ventral wing-like extensions, these being more ventrally oriented than in the case of the first primibrachial (Figure 48). Judging from the rather robust structure of these elements, Saccocoma cf. schattenbergi cannot be considered to be purely planktonic, quite in contrast to the other species mentioned in this report.

The peculiar axillary of Figure 51 as well as the proximal brachial of Figure 52, with two muscular faces, cannot be determined at present.

\section{0-6-1, 19-21 cm (Figures 17-23, 58, 62)}

The material from this sample embraces more than 100 pieces, eight of which are radials of Saccocoma sp. (cf. S. subornata Sieverts-Doreck, manuscript name).

Figures 17 and 58 show two larger, very thin radials (Figure 58, the inner side) which are only slightly arched. The dorsal surface is reticulate while the inner (ventral) side has two ridges in the upper third portion (Figures $17 \mathrm{~b}$ and 58). The articular face is small and confined to the top middle of the plate; no details are visible. Two smaller radials, which may belong to the same species, are shown in Figures 18 and 62. The interior ridges are lacking but the size of the articular face is quite similar. The outer surface is covered with small thorn-like processes (Figure 62). Figure 19 as well as Figure 21 represent first primibrachials, also of Saccocoma cf. subornata, while Figure 20 shows a proximal brachial of the same species. S. subornata Sieverts-Doreck occurs in the "Weissjura Gamma" (Lower Kimmeridgian) of Southern Germany.

The pieces shown in Figure 22 and 23 (first primibrachials ?) cannot be classified presently, they may, according to Mrs. Doreck, represent a new species.

\section{5-33-4, 10-30 cm (Figures 24-27)}

Only 20 brachials exist from this sample. Many are provided with lateral wings which, on the proximal brachials, occur proximally (see Figure 24c). A more distal brachial, apparently of the same species, is represented in Figure 25. These two elements belong to a species of Saccocoma. Identification of the elements of Figures 26 and 27 is not possible.

\section{5-37-3, 22-40 cm (Figures 28-36, 61)}

This sample contains about 30 pieces, more than a third are bifurcated extensions of radials of Saccocoma cf. quenstedti Sieverts-Doreck (manuscript name), and some are shown in Figures 34, 35, 36 and 61. The articular face for the first primibrachial is quite easily visible in Figure 34b. It appears that the brachials figured (Figures 28 through 33) also belong to this species. The element of Figure 32 may be a first primibrachial, and that of Figure 28a, a second primibrachial (first axillary). The other elements seem to be secundibrachials (note the lateral wings in Figures 31 and 33 , obviously structures to facilitate planktonic life).

\section{5-38-2, 64-80 $\mathrm{cm}$ (Figures 44 and 45)}

This sample contains only 8 elements, two of which are figured. Their affinities are not at all clear to me, but Mrs. Doreck thinks them to be first primibrachials, possible of a new species of Saccocoma.

\section{5-38-5, 12-30 cm (Figures 37-43)}

This sample embraces 65 elements. They are brokenoff radial extensions of Saccocoma cf. quenstedti Sieverts-Doreck (Figures 40 and 41), and a number of quite diverse brachials. Figure 37 may represent a brachial of $S$. cf. schattenbergi Sieverts-Doreck, and the same is true for the piece of Figure 39. Figure 38 seems to show part of a radial with the typical fenestrate structure of $S$. cf. quenstedti (see Verniory, 1961, Figure 3 ). The element of Figure 42 is a proximal 
brachial (first primibrachial ?), the easily discernible outward-sloping articular face being a synostosis or cryptosynarthry. Figure 43 shows a more distal brachial with a pinnule socket, possibly of Saccocoma cf. subornata Sieverts-Doreck.

\section{REFERENCES}

Bather, F. A., 1924. Saccocoma cretacea n. sp. A Senonian crinoid. Proc. London Geol. Assoc. 35, 111.

Brönnimann, P., 1955. Microfossils incertae sedis from the Upper Jurassic and Lower Cretaceous of Cuba. Micropaleontology. 1(1),

Colom, G., 1955: Jurassic-Cretaceous pelagic sediments of the Western Mediterranean zone and the Atlantic area. Micropaleontology. 1(1), - .

Farinacci, A. and Sirna, G., 1959. Livelli a Saccocoma nel Malm dell'Umbria e della Sicilia. Boll. Soc. Geol. Ital. 79 Fasc. 3 , _.

Jaekel, O., 1892. Ueber Plicatocriniden, Hyocrinus und Saccocoma. Zeitschr. Deutsch. Geol. Ges. 44, 619.

Peck, R. E., 1943. Lower Cretaceous crinoids from Texas. J. Paleont. 17 (5), 451.

1948. A Triassic crinoid from Mexico. $J$. Paleontol. 22 (1), 81.

1955. Cretaceous microcrinoids from England. J. Paleontolo. 29(6), 1019.
Rasmussen, H. W., 1961. A monograph on the Cretaceous Crinoidea. Biol. Skr. Dan. Vid. Selsk. 12,(1),

Sieverts-Doreck, H., 1933. Ueber die Crinoidengattung Drepanocrinus Jaekel. Jahrb. Preuss. Geol. Landesant., Berlin. 53, 599.

1943. Armglieder von Roveacrinus aus einem norddeutschen Senongeschiebe. Zeitschr. Geschieb-Forschg. Flachlands Geol. 18 (2).

1955. Die Verbreitung Der Crinoidengattung Saccocoma im Schwäbischen Jura. Jh. Ver. Vaterl. Naturk. Württemberg. 110, 118.

Verniory, R., 1954. Eothrix alpina Lombard, Algue ou Crinoide? Arch. Sci. Genève. 7 (4), 327.

1956. La création du genre Lombardia Brönnimann est-elle justifiée ? Arch. Sci. Genève. 9 (1), 86 .

1960. Présence (et variétés) de Saccocoma tenella Goldfuss à Talloires (Haute-Savoie). Arch. Sci. Genève. 13(2), 250.

1961. Présence de Saccocoma quenstedti Doreck (in coll.) dans les gorges de la Méouge (Sisteron-Provence). Arch. Sci. Genève. 14 (2), 315. , 1962. Quelques considérations sur les Saccocomidés (échantillonnage, statistique, stratigraphie). Une nouvelle forme de Saccocoma (Montbrand, Hautes-Alpes, France). Arch. Sci. Genève. 15 (2), 388. 

Sample 100-4-1, 12-14 cm:

Figures 1-3 Broken-off lateral extensions of radials, Saccocoma cf. quenstedti Sieverts-Doreck (manuscript name). 1 and $2 b$ : ventral view. $2 a$ and 3 : dorsal view.

Figure 4 Lateral extension of radial, or brachial of $S$. cf. quenstedti Sieverts-Doreck.

Figure $5 \quad$ Primibrachial (?), Saccocoma sp. indet. a: proximal view. b: distal view.

Figure 6 Higher secundibrachial, Saccocoma sp. indet. a: dorsal view. b: ventral view.

Sample 100-4-1, 130-132 cm:

Figure 7 Radial (juvenile), group of Saccocoma cf. schattenbergi Sieverts-Doreck (manuscript name). a: ventral view. b: inner side. c: lateral view (turn $180^{\circ}$ ).

Figure $8 \quad$ Brachial, Saccocoma sp. a,b: articular faces.

Figure 9 First primibrachial, Saccocoma (new ?) sp. a: dorsal view. b: ventral view. c: lateral view.

Sample 100-5-2, 18-20 cm:

Figure 10 Second primibrachial, Saccocoma (new ?) sp. a: ventral side with proximal articular face. b: dorsal view. c: distal end.

Figure 11 First primibrachial, Saccocoma (new ?) sp. a: dorsal side with distal articular face. b: ventral view. c: distal end.

Figure 12 Non-identifiable skeletal element. a: proximal view (?). b: inner side. c: dorsal view.

Figure $13 \quad$ Brachial (?), Saccocoma (new ?) sp. a: proximal end (?). b: ventral view (?).

Figure $14 \quad$ Brachial (?), Saccocoma cf. subornata Sieverts-Doreck (manuscript name) (?). a: dorsal view. b: ventral view.

Figures 15,16 Brachials, Saccocoma sp. 15 and 16a: dorsal view. 16b: lateral view.

Sample 100-6-1, 19-21 cm:

Figures 17,18 Radials, Saccocoma sp., cf. subornata SievertsDoreck. a: lateral view. b: inner side.

Figure 19 First primibrachial, $S$. cf. subornata Sieverts-Doreck. a: dorsal side with distal articular face. b: ventral view.

Figure $20 \quad$ Proximal brachial, $S$. cf. subornata Sieverts-Doreck. a: dorsal view. b: ventral view. c,d: articular faces. 
PLATE 1

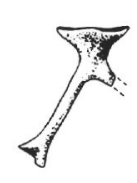

$$
\text { I }
$$

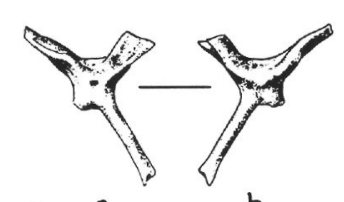

$2 a b$

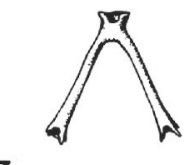

3

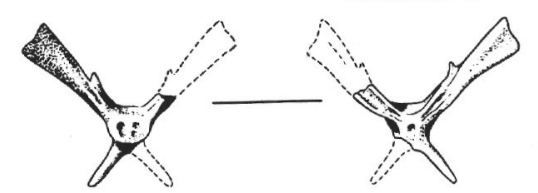

b

4
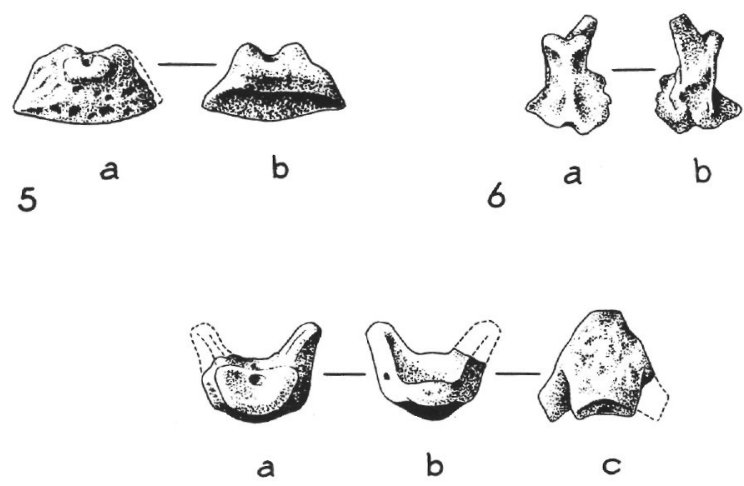

a

b

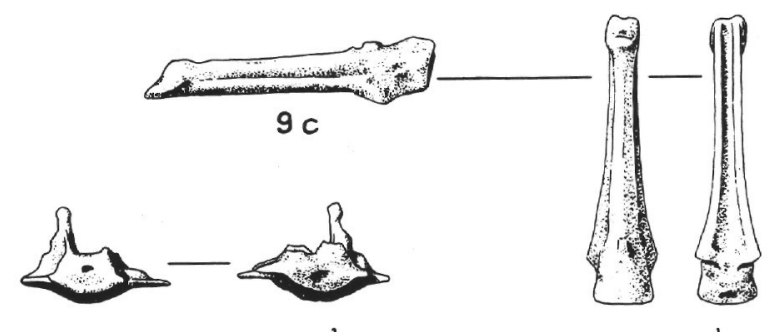

8
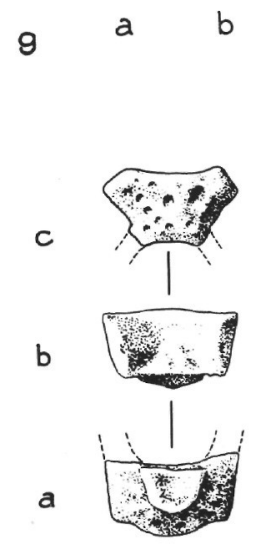

12

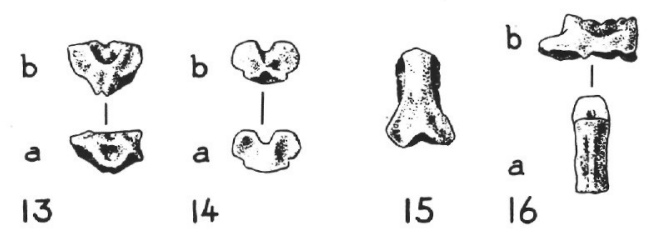

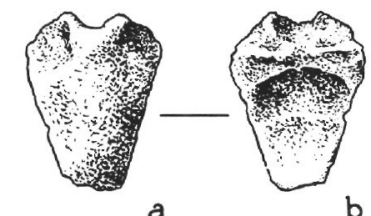

17

a

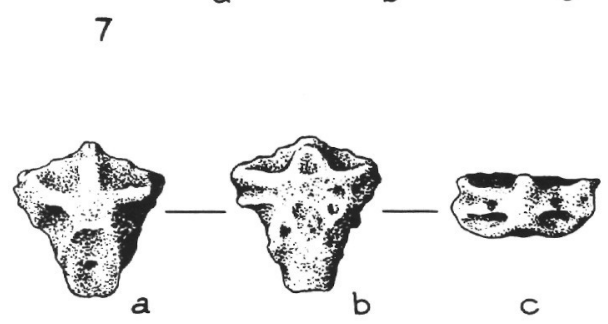

10
18

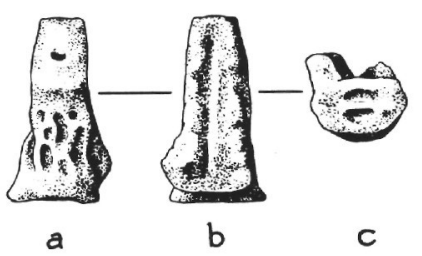

C

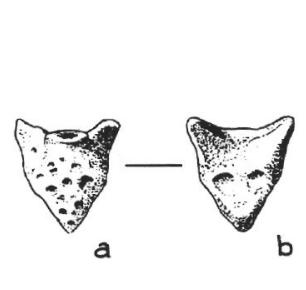

II

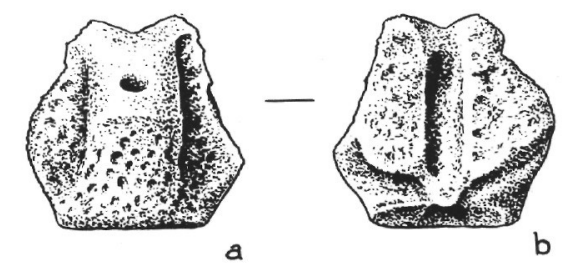

19

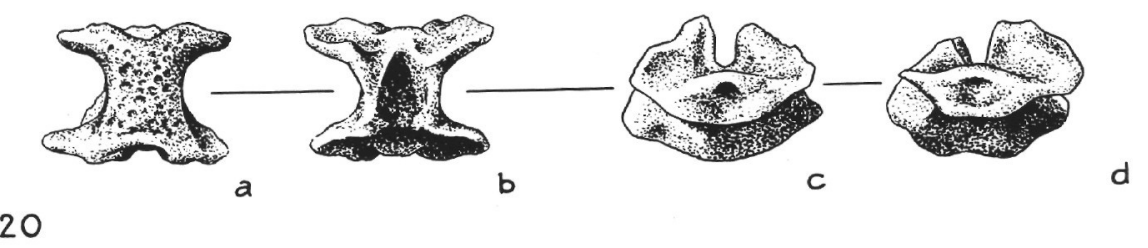


PLATE 2

Remains of saccocomids. Natural History Museum

Basel, M 8851-M 8875. (Figures 21-45).

Sample 100-6-1, 19-21 cm:

Figure $21 \quad$ First primibrachial (?), Saccocoma cf. subornata Sieverts-Doreck. (manuscript name). a: dorsal view. b: ventral view. c: lateral view.

Figures 22,23 First primibrachials (?), Saccocoma, sp. indet. (new sp. ?). a: lateral view; b: proximal view (?).

Sample 105-33-4, 10-30 cm:

Figure 24 Brachial, Saccocoma sp. indet. a: proximal view (?). b: distal view (?). c: dorsal view (?).

Figure 25 Distal brachial, Saccocoma sp. indet.

Figures 26,27 Non-identifiable elements. 26a,b: articular faces, 27a: proximal view. $27 \mathrm{~b}$ : dorsal view. $27 \mathrm{c}$ : lateral view.

Sample 105-37-3, 22-40 cm:

Figure 28 Second primibrachial (IAx ?) Saccocoma sp. (cf. quenstedti Sieverts-Doreck). a: proximal view. b: distal view.

Figure 29 Brachial, S. cf. quenstedti Sieverts-Doreck. Articular face.

Figure $30 \quad$ Brachial, S. cf. quenstedti Sieverts-Doreck. Dorsal view.

Figures 31,33 Secundibrachials (?), S. cf. quenstedti SievertsDoreck. a: dorsal side with distal articular face. b: ventral view.

Figure 32 First primibrachial (?), S. cf. quenstedti SievertsDoreck. Dorsal side with distal articular face.

Figures 34-36 Broken-off lateral extensions of radials, $S$. cf. quenstedti Sieverts-Doreck. 34b: ventral view; others probably dorsal views.

Sample 105-38-5, 12-30 cm:

Figure 37 Brachial, Saccocoma cf. schattenbergi Sieverts-Doreck (manuscript name). a: dorsal view. b: ventral view.

Figure $38 \quad$ Part of a radial (?), Saccocoma cf. quenstedti Sieverts-Doreck, a: dorsal view (?). b: ventral view (?).

Figure 39 Brachial, $S$. cf. schattenbergi Sieverts-Doreck. a,b: articular faces.

Figures 40,41 Broken-off lateral extensions of radials, $S$. cf. quenstedti Sieverts-Doreck.

Figure 42 Proximal brachial (first primibrachial ?), Saccocoma sp. indet.

Figure 43 Distal brachial with pinnule socket, $S$. cf. subornata Sieverts-Doreck. a: dorsal view. b: lateral view with articular face for pinnule.

Sample 105-38-2, 64-80 cm:

Figures 44,45 First primibrachials (?) of Saccocoma sp. (?) 
$4-1-1$

$21 \quad a \quad b$
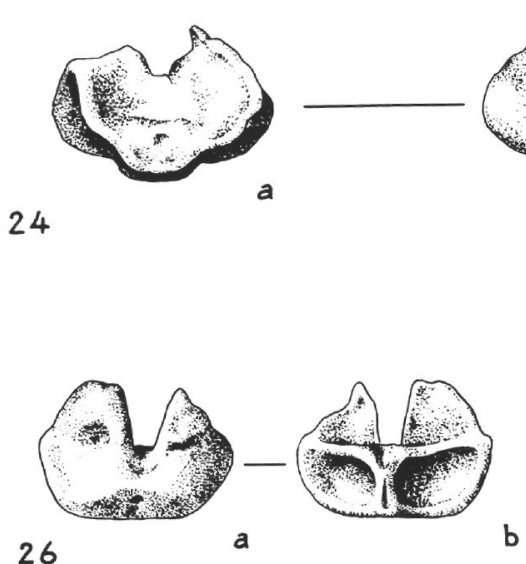

b
24

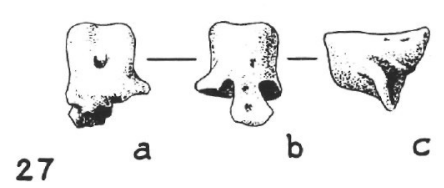

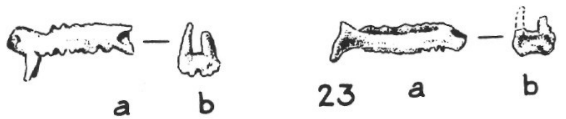

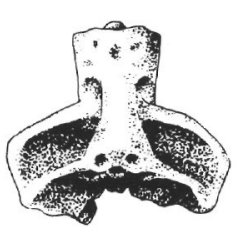

c

PLATE 2

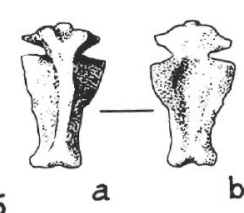

25
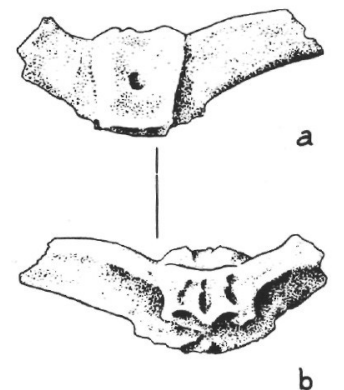

28
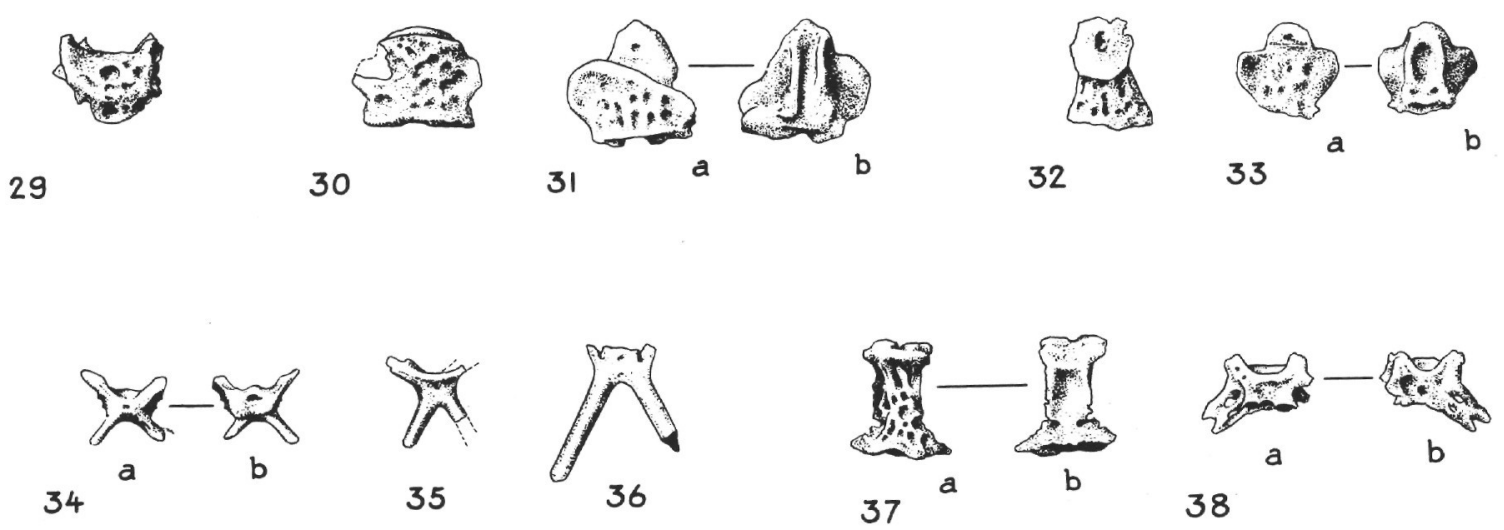

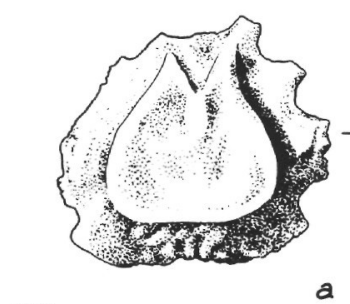

39

a

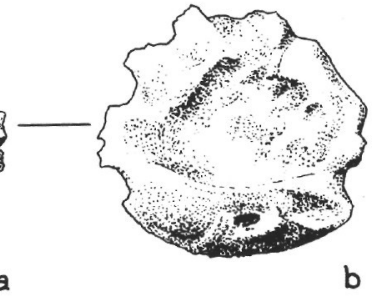

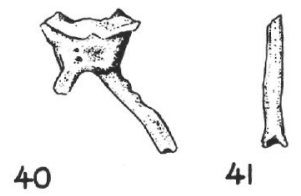

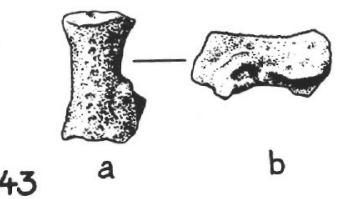

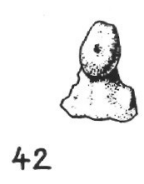

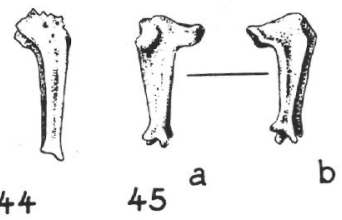


PLATE 3

Remains of saccocomids. Sample 100-5, core catcher, Natural History Museum Basel, M 8876-M 8883 (Figures 46-53)

Figures 46,47 Radials, Saccocoma cf. schattenbergi Sieverts-Doreck (manuscript name). a: lateral view. b: inner side. c: distal end with articular face.

Figure 48

First primibrachial, $S$. cf. schattenbergi SievertsDoreck. a: dorsal side with distal articular face. b: ventral side. c: lateral view. d: proximal end.

Figures 49,50 Proximal brachials, $S$. cf. schattenbergi SievertsDoreck. a,b: articular faces.

Figure 51 Axillary of unknown affinity. a: proximal view. b: distal view. c: dorsal view.

Figure 52 Proximal brachial, Saccocoma sp. indet. a,b: articular faces. c: ventral view. d: dorsal view.

Figure 53 Second primibrachial (IAx), S. cf. schattenbergi Sieverts-Doreck. a: dorsal view. b: ventral view. c: distal end. 

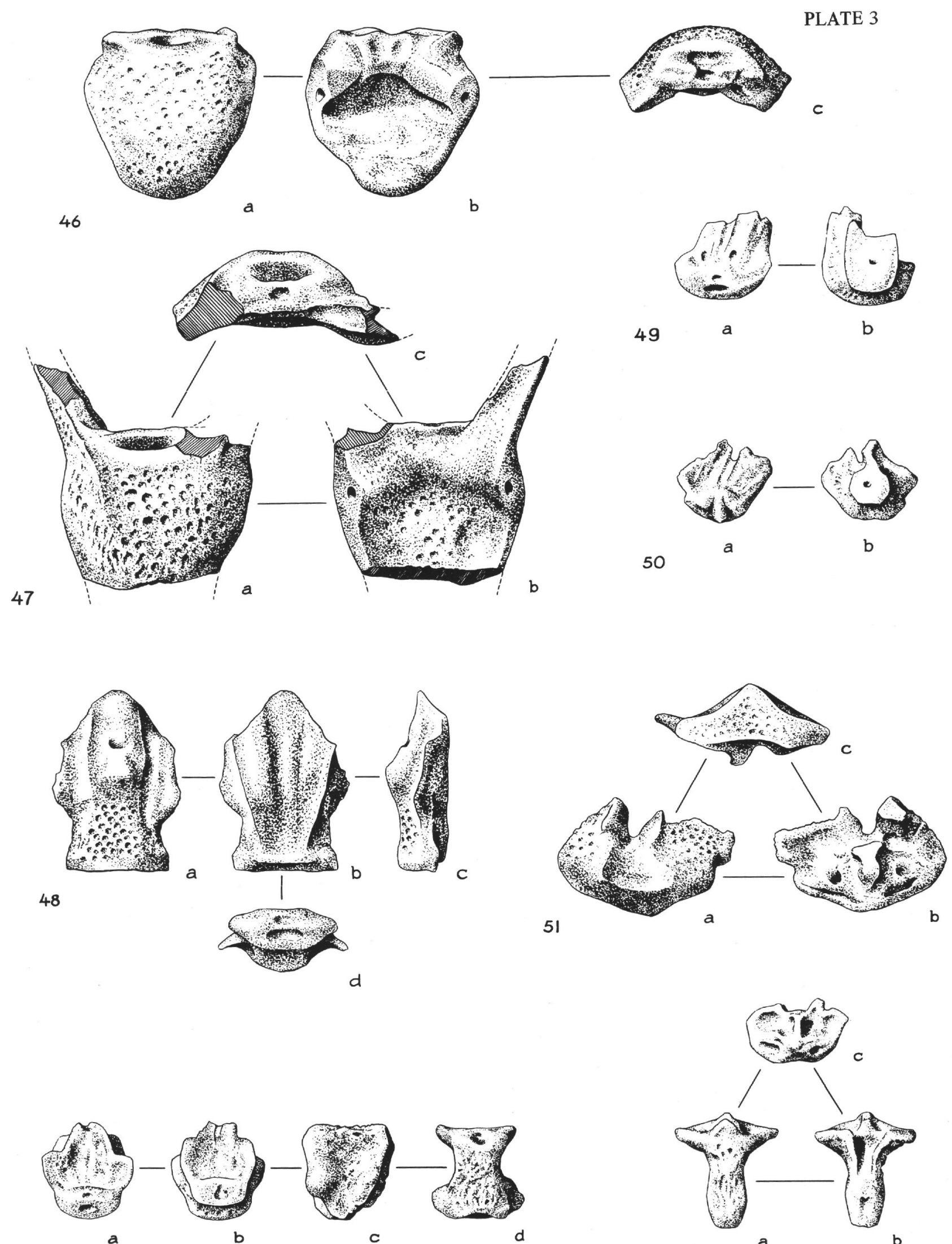

a

b

c

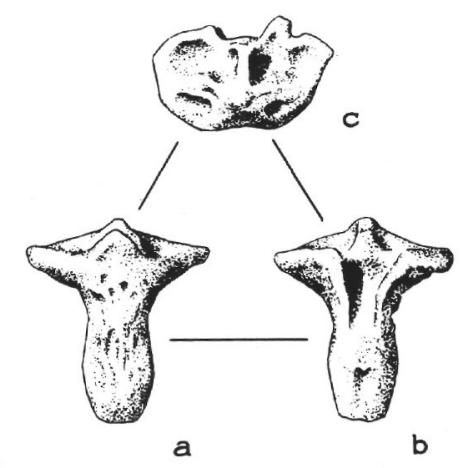




\section{PLATE 4}

Stereoscan electron micrographs of saccocomids, gold-coated, 70X. Natural History Museum

Basel M 8884-M 8895. (Figures 54-65)

Figures 54,55 Broken-off lateral extensions of radials, Saccocoma cf. quenstedti Sieverts-Doreck (manuscript name), Sample 99A -14, core catcher.

Figure 56

Dorsal view of brachial (higher secundibrachial ?) of Saccocoma sp. (note lateral wing still preserved on the right side). Sample 100-4-1, 12-14 cm.

Figure 57

Radial extension of Saccocoma cf. quenstedti Sieverts-Doreck. Sample 100-4-1, 12-14 cm.

Figures 58,62 Radials of Saccocoma sp. (cf. subornata SievertsDoreck, manuscript name). Figure 58: inner side. Figure 62: lateral view. Sample 100-6-1, 19-21 cm.

Figures 59,60,63 Proximal brachials, presumably of Saccocoma cf. schattenbergi Sieverts-Doreck (manuscript name). Figures 59, 60: articular faces (muscular and cryptosynarthrial). Figure 63: dorsal view, pinnule socket at right. Sample 100-5, core catcher.

Figure 61

Broken-off lateral extension of radial, $S$. cf. quenstedti Sieverts-Doreck, probably dorsal view. Sample 105-37-3, 22-40 cm.

Figures 64,65 Second primibrachials (IAx), Saccocoma sp. (n.sp. ?). Figure 64: ventral side with strongly inwardsloping cryptosynarthrial face. Figure 65: dorsal view. Sample 100-5-2, 18-20 cm. 


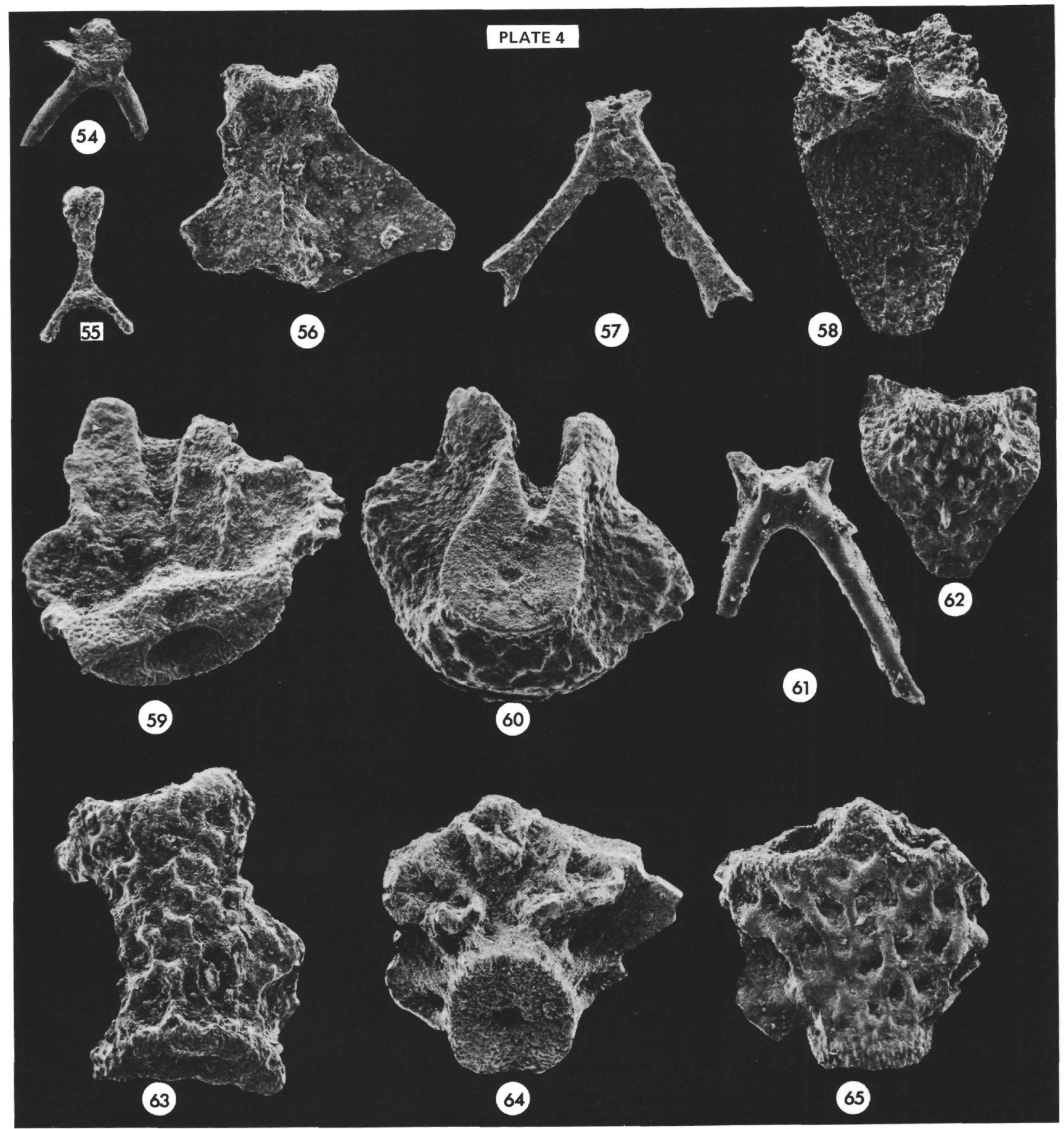

